\title{
Field-based quality indicators in degraded pasture of the Atlantic forest biome
}

\section{Paulo Roberto da Rocha Junior ${ }^{1, *}$, Guilherme Kangussú Donagemma ${ }^{2}$, Felipe Vaz Andrade ${ }^{1}$, Renato Ribeiro Passos ${ }^{1}$, Alexandre Sylvio Vieira da Costa ${ }^{3}$, Hugo Alberto Ruiz ${ }^{1}$}

\author{
${ }^{1}$ Universidade Federal do Espírito Santo, Department of Plant Production, Alto Universitário, Gurarema s/n, \\ Alegre, 29500-000, ES, Brazil \\ ${ }^{2}$ Empresa Brasileira de Pesquisa Agropecuária, Rua Jardim Botânico 1024, Jardim Botânico, 24460-000, Rio de \\ Janeiro, RJ, Brazil \\ ${ }^{3}$ Universidade Federal dos Vales do Jequitinhonha e Mucuri, Campus JK, Rua Cruzeiro 01, Jardim São Paulo, \\ 39803-371, Teófilo Otoni, MG, Brazil
}

*Corresponding author: rocha.pjunior@gmail.com

\begin{abstract}
Developing techniques that are easily accessible to producers and extension agents would facilitate the assessment of pasture degradation in rural areas. The objective of this work was to evaluate the sensitivity of field-based indicators of soil quality at different levels of degraded pastures, validate these indicators with those determined in laboratory. Six areas were chosen: four areas of pastures in different gradients of degradation visually assessed (Degraded Pasture $1-\mathrm{P}_{1}$; Degraded Pasture 2 - $\mathrm{P}_{2}$; Degraded Pasture $3-\mathrm{P}_{3}$; and Degraded Pasture $4-\mathrm{P}_{4}$ ), in descending order of degradation; an area of Capoeira (natural vegetation of soil recovery); and a secondary Forest used as reference. The soil under all areas was an Ultisol clayey, and field determinations used were: soil coverage rate $\left(\operatorname{Soil}_{\mathrm{Cov} . \mathrm{Rt}}\right)$, depth of the root system $\left(D_{R S}\right)$ and "A horizon" thickness. Laboratory determinations were: soil density, total porosity (Tp), macroporosity (Ma), microporosity (Mi), $\mathrm{Ca}^{2+}, \mathrm{Mg}^{2+}, \mathrm{Al}^{3+}, \mathrm{H}+\mathrm{Al}, \mathrm{P}, \mathrm{K}^{+}$, organic carbon (OC), base (BS) and aluminum saturation (AS). Also, the organic matter compartments such as particulate organic matter (POM), particulate organic carbon and carbon fraction associated with soil minerals were determined. Soil quality ranking were assigned to the different areas, and orthogonal contrasts were made to compare the stages of degradation. Subsequently, linear correlations were adjusted to test whether there were significant differences for the field and laboratory indicators among the areas of study. Soil quality ranking assigned represented the levels of degraded pasture visually observed in field, therefore allowing correlations with field indicators "A horizon" thickness (Rainy season $r=0.71$ and Dry season $r=0.91$ ) and $D_{R S}$ (Rainy season $r=0.81$ and dry season $r=0.58$ ). Similar correlations were found when the Soil ${ }_{\text {Cov. Rt }}$ was used, where correlations were observed with the "A horizon" thickness (Rainy season $r=0.61$ and Dry season $r=0.75$ ) and $D_{R S}$ (Rainy season $r=0.76$ and Dry season $r=0.84$ ). The field and laboratory determinations showed statistical differences between study areas, indicating that they were sensitive to levels of degradation. Through field determinations, it was possible to separate four groups of degradation: reference (Forest), low degradation $\left(\mathrm{P}_{4}\right.$ and $\left.\mathrm{P}_{3}\right)$, under recovery (Capoeira) and high degradation $\left(\mathrm{P}_{1}\right.$ and $\left.\mathrm{P}_{2}\right)$. The easily determined field-based quality indicators showed significant correlations with the laboratory values: BS, AS, Ma and POM, especially on the $0-5 \mathrm{~cm}$ surface layer, showing small variation between sampling periods and indicating the possibility of using these indicators to differentiate levels of degraded pastures with good accuracy.
\end{abstract}

Keywords: Ultisol, soil exposure, soil quality, root system.

Abbreviations: $\mathrm{P}_{1}$ pasture degraded 1; $\mathrm{P}_{2}$ pasture degraded 2; $\mathrm{P}_{3}$ pasture degraded 3; $\mathrm{P} 4$ pasture degraded 4; BS_base saturation; Al_aluminum saturation; POM_particulate organic matter; Ma_macroporosity; "A horizon" thickness_A horizon thickness; $\mathrm{D}_{R S \_}$depth of roots system; Soil ${ }_{\text {Cov. RT_Soil coverage rate. }}$

\section{Introduction}

Population growth, increases life expectancy and trends in consumption have significantly increased pressure on the use of natural resources (Brown et al., 2011), by intensifying food production on existing areas and expansion of agriculture into virgin areas. In Brazil, the expansion has been occurring for decades, especially in the Atlantic Forest Biome, where degradation began with colonization 500 years ago (Dean, 1995). Currently, approximately $15 \%$ of the original territory remains preserved (Ribeiro et al., 2009).

Due to its great territorial extension and climate variability, soil and topography, the Atlantic Forest is one of the hotspots that has greater biodiversity and greater susceptibility to degradation and productive capacity loss (Fonseca, 1985). Thousands of hectares of rainforest have been converted into grazing areas (Myers et al., 2000), which are in a critical stage of degradation. The Zona da Mata pastures of Minas Gerais are an example of this (Nascimento et al., 2006). In various parts of this region, about $70 \%$ of the grazing areas are facing moderate levels of degradation. On the other hand, in the Vale do Rio Doce, an important water resource of the State of Minas Gerais, agricultural activities have caused the region to become quite degraded within the Atlantic Forest 
biome (Rocha Junior et al., 2014a; Silva et al., 2010). Few studies have been conducted on strategies to mitigate the pastures degradation of the Vale do Rio Doce region (Baruqui et al, 1985; Favero et al., 2008; Lima et al., 2008; Rocha Junior et al., 2014a; Rocha Junior et al., 2014b), thus increasing the environment, economic and social damage. To reverse the process of degradation, it is important to develop low cost and simple techniques to assess the impact of grassland management on soil quality, which can be easily used by qualified extension workers and producers (Lisbôa et al., 2016). However, the costs of monitoring the management systems may be high and the success of the methods, in general, may be hard to evaluate (Ruiz-Jaen and Aide, 2005; Rodrigues et al., 2009). One of the most used techniques to evaluate the impact of soil management has been the monitoring of some attributes of the soil and the establishment of soil quality indexes (Hulugalle et al., 1999; Islam and Weil, 2000; Andrews and Carroll, 2000; Passos et al., 2015; Bertosi et al., 2016; Lisbôa et al., 2016). However, assessment of the indexes or soil quality levels is not a simple task, representing a high cost for laboratory analyses. The assessment is very subjective because the soil is a complex body with numerous physical, chemical and biological processes, which often may be difficult to measure (Kelting et al., 1999). In this sense, adoption of environmental variables for easy measurement in the field becomes a desirable option, because besides providing easily interpretable results, it may be have low cost.

The objectives of the present study were to evaluate the sensitivity of field indicators of soil quality at different levels of degraded pastures, and to validate these easily determined field-based indicators with certain laboratory indicators.

\section{Results}

\section{Soil quality levels and relation with field indicators of soil} quality

The greatest value for the "A horizon" thickness was observed in the dry season, $23.76 \mathrm{~cm}$ compared to $21.89 \mathrm{~cm}$ of the rainy season (Fig. 1). The biggest value of depth of the root system $\left(D_{R S}\right)$ was also verified during the rainy season, $31.13 \mathrm{~cm}$ compared to $20.62 \mathrm{~cm}$ in the dry season (Fig. 1). In general, the lowest mean values corresponding to the "A horizon" thickness occurred in the dry season $(3-27 \mathrm{~cm})$, but the same trend was not observed when the $D_{R S}$ was evaluated (Fig. 1).

The quality level of the soil that presents the biggest average values of "A horizon" thickness and $D_{R S}$ is index 6 , concerning the Forest area; the lowest average values were observed in levels 1 and 2 (Fig. 1), which are pasture areas with greatest visual exposure of the soil.

The "A horizon" thickness and $D_{R S}$ were significantly higher in the Forest area than the other areas (Table 1, $\mathrm{C}_{1}$ ). A similar behavior was observed when comparing the Capoeira with the other areas, in which mean contrast values were significantly higher than the Pastures (Table $1, \mathrm{C}_{2}$ ). Among the pasture areas, Pasture 4 in general presented $D_{R S}$, and $\mathrm{A}$ horizon" thickness significantly higher than the other pastures (Table 1, $\mathrm{C}_{3}$ ).

When the soil coverage rate (Soil $\mathrm{Cov}_{\mathrm{RT}}$ ) was evaluated, it was confirmed that the areas with greater visual soil degradation, showed greater exposure of the soil by the "measuring tape" method (Pasture 1 and 2), and the Pasture areas with greater coverage visually observed (Pastures 3 and 4) had less soil exposure (Fig. 2). In the Pasture 2 area, less percent of soil was covered with grass when compared to
Pasture 1, but a higher rate was covered by two types of spontaneous plants, narrow and wide leaves. The Forest and Capoeira areas were fully covered (Fig. 2). The weightings assigned to soil quality levels were appropriate to the objectives of the research, since they showed significant linear correlation coefficients with the Soil Cov. RT $_{\text {R }} r=-$ $0.97 * * *$ for the rainy season and $r=-0.89 * *$ for the dry period), showing that the level with the lowest weight represents the largest exposure of the soil, and the level with the higher weight represents absence of soil disturbance. These results suggest that for both, weightings assigned to soil quality levels and field determination by the "measuring tape" method, the trend was the same. When the correlations were adjusted using the soil exposure levels observed by the "measuring tape" method, the soil quality levels showed higher $r$ values. The exception was the root growth in the dry period (Fig. 1).

Validation of field indicators of soil quality by laboratory indicators

When the physical, chemical indicators and the compartments of organic matter were evaluated, the most sensitive in differentiating visually observed soil management and detecting the variation of soil quality in different areas were: the base saturation (BS), aluminum saturation (AS), particulate organic matter (POM) and macroporosity (Ma) (Table 2). In general, the numerically smallest mean values of chemical and physical attributes were observed in pasture areas with greater soil exposure (Pastures 1 and 2). On the other hand, the areas with the greatest vegetation coverage (Forest and Capoeira) showed higher mean values, and Pastures 3 and 4 showed intermediate values (Table 2 and 3). Significant differences were observed between the areas of study, especially when comparing the Forest area with the other areas, and Capoeira with the Pastures (Table 3, $\mathrm{C}_{1}$ and $\mathrm{C}_{2}$ ). Among the pasture areas, Pasture 2 followed by Pasture 4 and Pasture 3, are the areas with the best chemical soil attributes, with the smallest AS and largest BS. On the other hand, no differences were observed for POM in the pastures (Table 2 and $3, \mathrm{C}_{3}$ and $\mathrm{C}_{4}$ ). In general, for all areas a decrease in the $\mathrm{BS}$ and POM values occurred with increasing depth, especially in the 20-40 m layer (Table 2). Within the soil profile, little variation was observed for the Ma, but highest mean values were observed in the Forest (Table 2 and 3). Comparing the pastureland areas, the soil under Pasture 4 at all depths had Ma values higher than the other pastures in the rainy season (Table 3, $\mathrm{C}_{3}$ ). In the dry season, no differences were observed, the soil under Pasture 4, at all depths, had mean values numerically higher for this attribute when compared with areas with

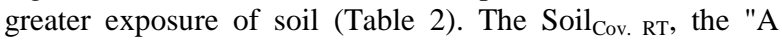
horizon" thickness and $D_{R S}$, in a general manner, in both sampling periods, had a close relationship with the laboratory indicators, with little variation for the correlations for the collection periods (Table 4). The surface layer $(0-5 \mathrm{~cm})$ was the most sensitive to indicate the best soil quality parameters (Table 4 and 5). Differences are also observed at 5-10, 10-20 and $20-40 \mathrm{~cm}$, but the significance level was lower (Table 4). Regarding field indicators, with the exception of "A horizon" thickness, the variation between the seasons was very small, indicating that the use of indicators, both lab and field, is independent of the sampling period (Table 5). The increased exposure is linked with all the other indicators as shown by the correlations. A decrease in soil Ma, as well as in the POM 
Table 1. Contrast of mean average in field determinations for Ultisol clayey in two seasons rainy and dry.

\begin{tabular}{|c|c|c|c|c|}
\hline \multirow{2}{*}{$\begin{array}{l}\text { Orthogonal } \\
\text { contrasts }\end{array}$} & \multicolumn{2}{|c|}{ Rainy season } & \multicolumn{2}{|c|}{ Dry season } \\
\hline & "A"/B & $D_{R S}^{\text {IC }}$ & "A" & $D_{R S}$ \\
\hline $\mathrm{C}_{1}$ & $81.75 * *$ & 117.00 ** & $43.40 *$ & $63.48 *$ \\
\hline $\mathrm{C}_{2}$ & $21.20 * *$ & $20.89 * *$ & $3.80^{*}$ & 1.80 \\
\hline $\mathrm{C}_{3}$ & 5.00 & $34.60 * *$ & $40.67 * *$ & $41.33 * *$ \\
\hline $\mathrm{C}_{4}$ & $46.40 * *$ & $42.40 * *$ & $12.48^{*}$ & $23.95^{*}$ \\
\hline $\mathrm{C}_{5}$ & -4.40 & 2.00 & $8.48 *$ & 9.89 \\
\hline
\end{tabular}

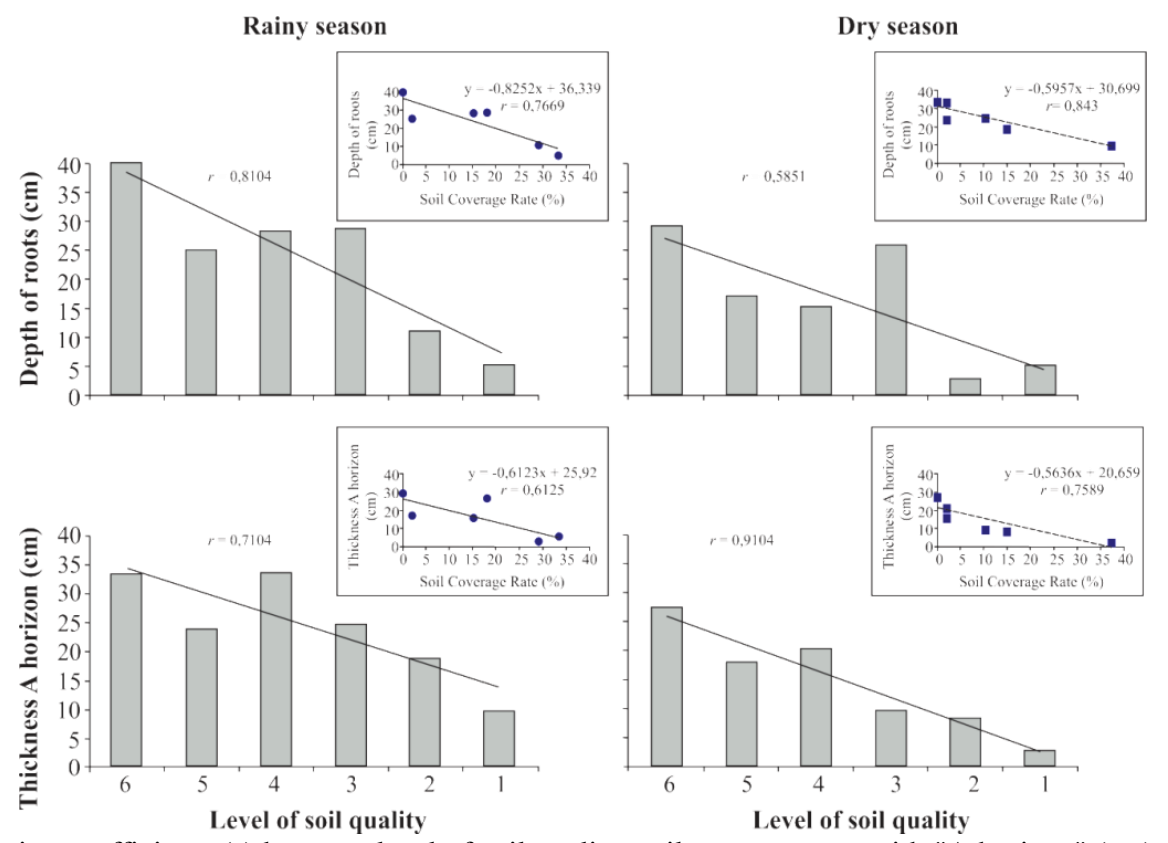

Fig 1. Linear correlation coefficients $(r)$ between level of soil quality, soil coverage rate with "A horizon" (cm) thickness and Depth of roots system $(\mathrm{cm})\left(D_{R S}\right)$ for the two seasons, rainy and dry in Ultisol clayey. (1) Degraded Pasture 1, (2) Degraded Pasture 2, (3) Degraded Pasture 3, (4) Degraded Pasture 4, (5) Capoeira and (6) Forest.

contents was observed. In addition, the increase of exposure of the soil caused an increase in the AS and consequently, a reduction in the BS (Table 2 and 4). The order of highest correlation between field and laboratory indicators is: AS = $\mathrm{BS} \gg \mathrm{Ma}>\mathrm{MOP}$. These results show that the field determinations, used as soil quality indicators are sensitive to the levels of degraded pastures observed visually, since they present little variation between the seasons, and good relations with the laboratory indicators, thus validating the field indicators. Significant correlations between field indicators of the soil quality were observed; the greater "A horizon" thickness the higher $D_{R S}$ or vice versa $(r=0.87 * *$ Rainy season and $r=0.78 * *$ Dry season).

\section{Discussion}

In this study, differences in the degraded pasture areas can be identified by means of field indicators. The striking differences shown by the results (Table 1) illustrate the sensitivity of the field determinations when used as soil quality indicators. The use of the soil quality levels were appropriate for the proposed soil quality assessment in the various degraded pastures observed in the field. The same behavior was seen in the correlations when the "measuring tape" method was used, proving that the use of a more practical method was justified. In this sense, visual evaluation methods of soil quality can provide a quick and easy analysis producing semi-quantitative results (Munkholm et al., 2013). This approach allows us to evaluate the subjectivity of soil quality indexes, which have the potential to be used by extension workers and farmers. The results showed that the coverage rate and $D_{R S}$ were the most effective parameters in showing differences between the studied areas. Although the "A horizon" thickness showed differences between areas, the relationship between the sampling periods were weaker (Table 5). From the correlations, it is possible to verify the hypothesis of increasing Soil ${ }_{\text {Cov. RT }}$ led to higher losses of "A horizon" and reduced $D_{R S}$. This result is indicative of the occurrence of erosion processes in the pasture and Capoeira areas after the removal of natural vegetation, as well as the greater intensity of grazing above the pasture carrying capacity, causing compaction and, consequently, soil erosion. From the field indicators, the best soil conditions were observed in the Forest area, followed by the Capoeira area. Pastures 3 and 4 behaved similarly showing intermediate quality, and the worst soil conditions were observed in Pasture areas 1 and 2. The largest "A horizon" thickness found in the Forest compared to the other areas might be related to mechanisms that promote the least soil loss in those areas, for example: a canopy with diversified foliage providing interception of raindrops, resulting in increased soil protection (Martin and Timmer, 2006); the deposition of a layer rich in leaves and 
Table 2. Mean values of soil chemical and physical properties and organic matter pools in levels of degraded Pastures, Capoeira and Forest sites, at two seasons rainy and dry, in Ultisols clayey.

\begin{tabular}{|c|c|c|c|c|c|c|c|c|c|}
\hline \multirow{3}{*}{ Sites } & \multirow{3}{*}{$\begin{array}{l}\text { Depth } \\
\text { (cm) }\end{array}$} & \multicolumn{4}{|c|}{ Rainy season } & \multicolumn{4}{|c|}{ Dry season } \\
\hline & & $\mathrm{BS}^{/ \mathrm{A}}$ & $\mathrm{AS}^{/ \mathrm{B}}$ & \multirow{2}{*}{$\begin{array}{c}\mathrm{POM}^{/ \mathrm{C}} \\
\text { g O.M. kg }{ }^{-1} \text { soil }\end{array}$} & \multirow{2}{*}{$\begin{array}{l}\mathrm{Ma}^{\mathrm{Id}} \\
\mathrm{m}^{3} \mathrm{~m}^{-3}\end{array}$} & BS & AS & \multirow{2}{*}{$\begin{array}{c}\mathrm{POM} \\
\text { g O.M. } \mathrm{kg}^{-1} \text { soil }\end{array}$} & \multirow{2}{*}{$\begin{array}{c}\mathrm{Ma} \\
\mathrm{m}^{3} \mathrm{~m}^{-3}\end{array}$} \\
\hline & & \multicolumn{2}{|c|}{$\%$} & & & \multicolumn{2}{|c|}{$\%$} & & \\
\hline \multirow{4}{*}{ Forest } & $0-5$ & 54.60 & 1.30 & 13.71 & 0.22 & 47.90 & 1.00 & 12.70 & 0.27 \\
\hline & $5-10$ & 42.30 & 4.40 & 13.32 & 0.22 & 41.70 & 3.30 & 12.06 & 0.27 \\
\hline & $10-20$ & 44.00 & 7.00 & 13.39 & 0.29 & 31.80 & 10.30 & 11.41 & 0.33 \\
\hline & $20-40$ & 39.10 & 7.90 & 12.42 & 0.22 & 31.30 & 13.60 & 10.35 & 0.27 \\
\hline \multirow{4}{*}{ Capoeira } & $0-5$ & 52.80 & 0.00 & 8.86 & 0.09 & 58.60 & 2.60 & 9.54 & 0.13 \\
\hline & $5-10$ & 43.20 & 0.00 & 8.93 & 0.09 & 48.80 & 4.80 & 9.20 & 0.13 \\
\hline & $10-20$ & 41.10 & 2.50 & 7.41 & 0.33 & 17.50 & 6.40 & 8.77 & 0.10 \\
\hline & $20-40$ & 40.30 & 1.50 & 6.31 & 0.09 & 39.00 & 4.30 & 7.00 & 0.13 \\
\hline \multirow{4}{*}{${ }^{\mathrm{E} /} \mathrm{D}$. Pasture 1} & $0-5$ & 20.80 & 37.80 & 9.16 & 0.11 & 20.50 & 32.90 & 9.24 & 0.14 \\
\hline & $5-10$ & 15.00 & 60.40 & 7.96 & 0.11 & 15.40 & 57.50 & 8.27 & 0.14 \\
\hline & $10-20$ & 9.60 & 70.30 & 7.33 & 0.11 & 11.10 & 65.80 & 8.09 & 0.16 \\
\hline & $20-40$ & 8.00 & 80.50 & 6.42 & 0.11 & 10.10 & 73.30 & 7.54 & 0.14 \\
\hline \multirow{4}{*}{ D. Pasture 2} & $0-5$ & 7.80 & 74.70 & 8.69 & 0.18 & 10.50 & 66.10 & 8.78 & 0.18 \\
\hline & $5-10$ & 6.00 & 82.10 & 7.53 & 0.18 & 6.70 & 16.90 & 7.40 & 0.18 \\
\hline & $10-20$ & 6.10 & 82.00 & 7.03 & 0.20 & 5.90 & 83.90 & 6.92 & 0.21 \\
\hline & $20-40$ & 4.60 & 85.80 & 7.06 & 0.18 & 6.00 & 84.60 & 6.52 & 0.18 \\
\hline \multirow{4}{*}{ D. Pasture 3} & $0-5$ & 33.30 & 8.80 & 8.39 & 0.12 & 34.30 & 11.40 & 8.66 & 0.19 \\
\hline & $5-10$ & 21.20 & 32.80 & 8.21 & 0.12 & 30.80 & 27.90 & 7.14 & 0.19 \\
\hline & $10-20$ & 17.20 & 47.70 & 7.41 & 0.16 & 24.60 & 37.60 & 6.86 & 0.20 \\
\hline & $20-40$ & 19.00 & 40.00 & 6.45 & 0.12 & 23.10 & 40.40 & 6.55 & 0.19 \\
\hline \multirow{4}{*}{ D. Pasture 4} & $0-5$ & 30.90 & 4.80 & 7.30 & 0.19 & 29.00 & 17.50 & 8.00 & 0.17 \\
\hline & $5-10$ & 28.10 & 20.30 & 7.29 & 0.19 & 22.40 & 36.70 & 7.53 & 0.17 \\
\hline & $10-20$ & 26.80 & 23.90 & 6.74 & 0.12 & 22.10 & 37.60 & 7.00 & 0.21 \\
\hline & $20-40$ & 26.20 & 27.80 & 6.50 & 0.19 & 21.50 & 39.30 & 7.22 & 0.17 \\
\hline
\end{tabular}

${ }^{\mathrm{A} /}$ Base saturation; ${ }^{\mathrm{B} /}$ Aluminum saturation; ${ }^{\mathrm{C} /}$ Particulate organic matter; ${ }^{\mathrm{d} /}$ Macroporosity; ${ }^{\mathrm{E} /}$ Degraded Pasture.

SOIL COVERAGE RATE

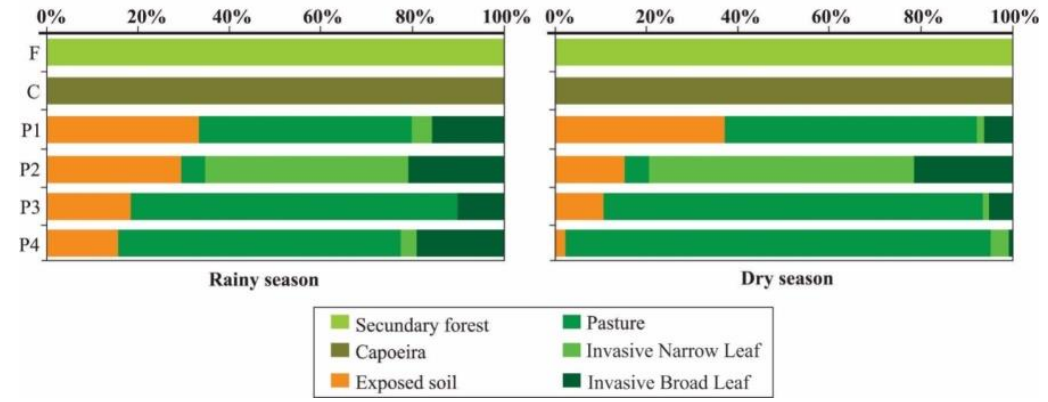



vegetation residues (litter) that raise the organic matter level, conditioning aggregates of greater stability and, therefore, providing better structure and increased soil permeability (Albuquerque et al., 2001; Malhotra et al., 2003; Tobiasova, 2011). On the other hand, the biggest $D_{R S}$ in the Forest area is related to the better structural conditions found in the "A horizon" which in addition to providing better aeration and water supply, is richer in nutrients, thus facilitating root growth. The Forest shows a pivoting root system that tends to grow more vertically than the fasciculate root system of the grasses. The smaller "A horizon" thickness and the lower $D_{R S}$ observed in Pastures 1 and 2 can be caused by the greater intensity of use in these areas which led to increased exposure of the soil. It should be noted that the greater exposure of soil is responsible for the larger soil loss by water erosion, which leads to reduction of the "A horizon" thickness, creating an inadequate environment for root development. The underlying textural "B" (Bt) horizon exhibits a physical impediment to root growth due to reduced macroporosity (Santana et al., 2006). When the sampling periods were evaluated, it was found that for the "A horizon" thickness there was no significant correlation, indicating that there may occur a distinct behavior between sampling times (Table 5). Despite that, the trend for both assessment times for this determination was similar, verified by the correlations and by contrasts, in which the Forest soil area showed more "A horizon" thickness when compared to soils of the other areas, and the soil under Capoeira was significantly higher than the soil under the Pastures $(4,3,2$ and 1) (Fig. 1 and Table 7). The differences seen during the sampling periods found for "A horizon" thickness may be related to variability of soil thickness within the same portion of land, despite the landform being convex. It should be noted that in declivitous areas, laminar erosion is nonuniform. Factors such as slope, curvature and the soil type, can naturally lead to these soil thickness variations 
Table 3. Orthogonal contrasts of soil chemical and physical properties and organic matter pools in degraded Pastures, Capoeira and Forest sites, at two seasons rainy and dry, in Ultisols clayey.

\begin{tabular}{|c|c|c|c|c|c|c|c|c|}
\hline \multirow{2}{*}{${ }^{\mathrm{A} /}$ Orthogonal contrasts } & \multicolumn{4}{|c|}{ Rainy season } & \multicolumn{4}{|l|}{ Dry season } \\
\hline & $\mathrm{BS}^{/ \mathrm{B}}$ & $\mathrm{AS}^{/ \mathrm{C}}$ & $\mathrm{POM}^{/ \mathrm{D}}$ & $\mathrm{Ma}{ }^{\mathrm{E}}$ & $\mathrm{BS}$ & AS & POM & $\mathrm{Ma}$ \\
\hline & $0-5 \mathrm{~cm}$ & & & & & & & \\
\hline $\mathrm{C}_{1}$ & $20,7 * *$ & $-122.16^{* *}$ & $28.54 * *$ & $0.46 * *$ & $87.51 * *$ & $-125.24 * *$ & $20.41 * *$ & $0.58 * *$ \\
\hline $\mathrm{C}_{2}$ & $79.81 * *$ & $-113.64 * *$ & 0.30 & -0.07 & $47.06^{* *}$ & $-124.73 * *$ & 0.00 & -0.04 \\
\hline $\mathrm{C}_{3}$ & $30.91 *$ & $-106.71 * *$ & -4.35 & $0.17 *$ & 21.76 & $-57.90 * *$ & 2.68 & 0.02 \\
\hline $\mathrm{C}_{4}$ & $37.97 * *$ & $-94.93 * *$ & -1.07 & -0.06 & $37.56 * *$ & $-76.17 * *$ & -0.69 & 0.05 \\
\hline \multirow[t]{2}{*}{$\mathrm{C}_{5}$} & $-12.99 *$ & $36.93 * *$ & -0.47 & $0.06^{*}$ & -9.97 & $33.20 * *$ & -0.46 & 0.05 \\
\hline & $5-10 \mathrm{~cm}$ & & & & & & & \\
\hline $\mathrm{C}_{1}$ & $92.28 * *$ & $-172.37 * *$ & $29.40 * *$ & $0.47 * *$ & $83.58 * *$ & $-145.39 * *$ & $22.33 * *$ & $0.58 *$ \\
\hline $\mathrm{C}_{2}$ & $73,13 * *$ & $-187.12 * *$ & 0.74 & -0.11 & $52.09 * *$ & $-74.97 * *$ & 1.19 & -0.04 \\
\hline $\mathrm{C}_{3}$ & $41.95 * *$ & $-114.64 * *$ & -1.81 & $0.17 *$ & 14.45 & 7.70 & -0.20 & 0.02 \\
\hline $\mathrm{C}_{4}$ & $21.22 *$ & $-76.91 * *$ & 0.92 & -0.06 & $39.53 * *$ & -18.56 & -1.40 & 0.05 \\
\hline \multirow[t]{2}{*}{$\mathrm{C}_{5}$} & -9.00 & $21.72 * *$ & -0.42 & $0.06^{*}$ & -8.71 & $-40.65 * *$ & -0.88 & 0.05 \\
\hline & $10-20 \mathrm{~cm}$ & & & & & & & \\
\hline $\mathrm{C}_{1}$ & $120.78 * *$ & $-186.44 * *$ & $34.73 * *$ & $0.66^{* *}$ & $74.48 * *$ & $-173.40 * *$ & 20.58 & $0.95^{* *}$ \\
\hline $\mathrm{C}_{2}$ & $68.06 * *$ & $-216.69 * *$ & 0.69 & $0.98 * *$ & $42.39 * *$ & $-212.27 * *$ & 1.79 & -0.24 \\
\hline $\mathrm{C}_{3}$ & $47.32 * *$ & $-128.23 * *$ & -1.54 & -0.10 & $24.70 *$ & $-74.44 * *$ & -0.88 & 0.02 \\
\hline $\mathrm{C}_{4}$ & 18.68 & $-56.90 * *$ & 0.46 & 0.01 & $32.22 * *$ & $-74.48 * *$ & -1.28 & 0.03 \\
\hline \multirow[t]{2}{*}{$\mathrm{C}_{5}$} & -3.50 & 11.71 & -0.30 & $0.09 *$ & -5.15 & $18.15^{*}$ & -1.16 & 0.05 \\
\hline & $20-40 \mathrm{~cm}$ & & & & & & & \\
\hline $\mathrm{C}_{1}$ & $97.42 * *$ & $-192.00 * *$ & $32.84 * *$ & $0.46 * *$ & $48.53 * *$ & $-163.59 * *$ & $19.46 * *$ & $0.58 *$ \\
\hline $\mathrm{C}_{2}$ & $60.28 * *$ & $-222.32 * *$ & 0.51 & -0.07 & $56.16 * *$ & $-226.43 * *$ & $-4.31 *$ & -0.04 \\
\hline $\mathrm{C}_{3}$ & $47.07 * *$ & $-122.99 * *$ & -0.43 & $0.17 * *$ & $25.37 *$ & $-80.34 * *$ & 1.06 & 0.02 \\
\hline $\mathrm{C}_{4}$ & $25.36 * *$ & $-86.23 * *$ & -0.57 & -0.06 & $30.10 * *$ & $-77.07 * *$ & -0.95 & 0.05 \\
\hline $\mathrm{C}_{5}$ & -3.34 & 5.27 & 0.64 & $0.06 *$ & -4.06 & 11.3 & -1.02 & 0.05 \\
\hline
\end{tabular}

Statistical significance shown: ${ }^{*} P<0.05 \% ;{ }^{* *} P<0.01 \%$ ( $F$-values). ${ }^{\mathrm{A}} \mathrm{C}_{1}$ : Forest vs Capoeira + Degraded Pasture (1- 4); $\mathrm{C}_{2}:$ Capoeira vs Degraded Pasture $(1-4)$; $\mathrm{C}_{3}$ : Degraded Pasture 4 vs Degraded Pasture (3-1); $\mathrm{C}_{4}$ : Degraded Pasture 3 vs Degraded Pasture (2 and 1); $\mathrm{C}_{5}$ : Degraded Pasture 2 vs Degraded Pasture 1. ${ }^{\mathrm{B} /}$ Base saturation. ${ }^{\mathrm{C}}$ Aluminum saturation. ${ }^{\mathrm{D} /}$ Particulate organic matter. ${ }^{\mathrm{E} /}$ Macroporosity.

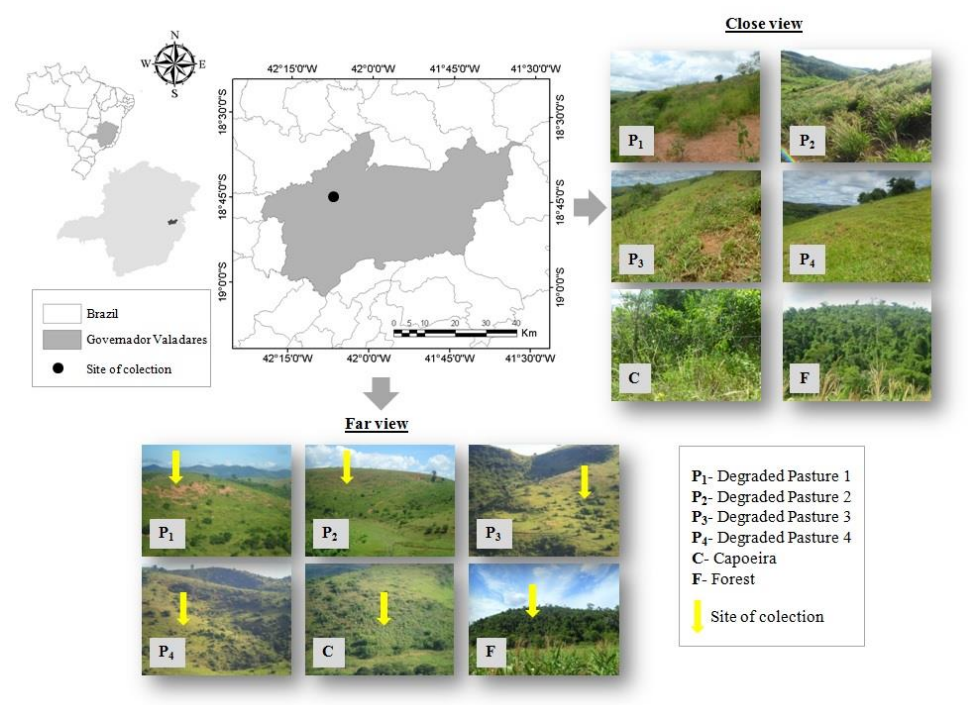

Fig 3. Location of Governador Valadares - MG, and site of colection.

(Vanwalleghem et al., 2010). Previous work in different land use (Landi et al., 2004; Manning et al., 2001) showed that the surface water run-off can largely control spatial patterns of soil depth, thus indicating what may be influencing this variation between seasons. As regards to the other indicators, the variation between the seasons was very small, suggesting that the use of laboratory and field indicators do not depend on the sampling period (Table 5). The values of $r$ were highly significant between laboratory and field indicators, especially in the surface $0-5 \mathrm{~cm}$ layer, which validates the field indicators as tools for the assessment of soil quality at local and regional scales. There were positive correlations between "A horizon" thickness, $\mathrm{D}_{R s}$, Ma, BS and POM. On the other hand, soil exposure correlates positively only with the AS
(Table 4). The negative correlations observed between the degree of soil exposure and POM, as well as $\mathrm{D}_{R s}$ and POM, relate especially to the areas of pasture lands. These areas have a higher rate of soil exposure and lower levels of POM, and lower $D_{R S}$ (Pastures 1, 2, 3, and 4) (Fig. 2 and Table 2). The POM reduction on pasture relates to lower litter production and deposition of above-ground plant litter, and reduced renewal of the root system, mediated by the process of soil degradation. These processes lead to a decline in productive areas and consequently reduced phytomass (Martínez and Zinck, 2004). The negative correlations observed between soil coverage rate and $\mathrm{BS}$, as well as $\mathrm{D}_{R s}$, relate to the increased exposure of the soil, which increases the nutrient loss by water erosion, especially the exchangeable 
Table 4. Linear correlation coefficients $(r)$ between chemical and physical properties, organic matter pools and field determinations for Ultisol clayey in two seasons rainy and dry.

\begin{tabular}{|c|c|c|c|c|c|c|c|c|}
\hline & \multicolumn{4}{|c|}{ Rainy season } & \multicolumn{4}{|c|}{ Dry season } \\
\hline & ${ }^{\mathrm{A} /} \mathrm{Ma}$ & ${ }^{\mathrm{B} / \mathrm{POM}}$ & ${ }^{\mathrm{C} / \mathrm{BS}}$ & ${ }^{\mathrm{D} / \mathrm{AS}}$ & $\mathrm{Ma}$ & POM & $\mathrm{BS}$ & AS \\
\hline & $0-5 \mathrm{~cm}$ & & & & & & & \\
\hline POM & $0.53 *$ & & & & $0.52 *$ & & & \\
\hline BS & 0.33 & $0.77 * *$ & & & 0.32 & $0.70 * *$ & & \\
\hline AS & -0.18 & $-0.65 * *$ & $-0.81 * *$ & & -0.16 & $-0.69 * *$ & $-0.90 * *$ & \\
\hline E/ "A" & 0.33 & $0.66 * *$ & $0.77 * *$ & $-0.75 * *$ & $0.39^{\circ}$ & 0.30 & $0.49 *$ & $-0.43^{\circ}$ \\
\hline${ }^{\mathrm{F} /} D_{R S}$ & $0.37^{\circ}$ & $0.80 * *$ & $0.77 * *$ & $-0.71 * *$ & 0.18 & $0.54 *$ & $0.49 *$ & $-0.47^{\mathrm{o}}$ \\
\hline \multirow{2}{*}{${ }^{\mathrm{G} /}$ Soil $_{\mathrm{Cov} . \mathrm{Rt}}$} & $-0.46^{\mathrm{o}}$ & $-0.87 * *$ & $-0.89 * *$ & $0.74 * *$ & $-0.45^{\circ}$ & $-0.73 * *$ & $-0.63 * *$ & $0.56 *$ \\
\hline & $5-10 \mathrm{~cm}$ & & & & & & & \\
\hline POM & 0.07 & & & & -0.24 & & & \\
\hline BS & 0.34 & 0.21 & & & 0.29 & 0.18 & & \\
\hline AS & -0.26 & -0.26 & $-0.92 * *$ & & $-0.44^{\mathrm{o}}$ & 0.03 & $-0.57 *$ & \\
\hline "A" & 0.33 & -0.11 & $0.72 * *$ & $-0.79 * *$ & $0.39^{\circ}$ & 0.25 & $0.46^{\circ}$ & $-0.55^{*}$ \\
\hline$D_{R S}$ & $0.37^{\circ}$ & 0.01 & $0.76 * *$ & $-0.77 * *$ & 0.18 & $0.33^{\circ}$ & $0.48 *$ & $-0.61 * *$ \\
\hline \multirow[t]{2}{*}{ Soil $_{\text {Cov. Rt }}$} & $-0.46^{\circ}$ & -0.18 & $-0.88 * *$ & $0.85 * *$ & $-0.45^{\circ}$ & $-0.42^{\circ}$ & $-0.62 * *$ & $0.64 * *$ \\
\hline & $10-20 \mathrm{~cm}$ & & & & & & & \\
\hline POM & $-0.46^{\mathrm{o}}$ & & & & $-0.39^{\circ}$ & & & \\
\hline BS & $0.39^{\circ}$ & 0.28 & & & 0.01 & 0.06 & & \\
\hline AS & -0.24 & -0.43 & $-0.94 * *$ & & -0.09 & -0.12 & $-0.96 * *$ & \\
\hline "A" & $0.41^{\circ}$ & -0.06 & $0.74 * *$ & $-0.77 * *$ & $0.61 * *$ & -0.27 & $0.50 *$ & $-0.58 *$ \\
\hline$D_{R S}$ & $0.48^{\circ}$ & 0.08 & $0.84 * *$ & $-0.82 * *$ & 0.21 & $-0.46^{\circ}$ & $0.57 *$ & $-0.58 *$ \\
\hline \multirow[t]{2}{*}{ Soil $_{\text {Cov. Rt }}$} & $-0.48^{\circ}$ & -0.20 & $-0.91 * *$ & $0.89 * *$ & -0.23 & $0.35^{\circ}$ & $-0.69 * *$ & $0.71 * *$ \\
\hline & $20-40 \mathrm{~cm}$ & & & & & & & \\
\hline POM & -0.31 & & & & -0.32 & & & \\
\hline BS & $0.49^{\circ}$ & 0.04 & & & 0.31 & $-0.52 *$ & & \\
\hline AS & $-0.38^{\circ}$ & -0.12 & $-0.96 * *$ & & -0.27 & $0.44^{\circ}$ & $-0.95 * *$ & \\
\hline "A" & 0.33 & 0.14 & $0.73 * *$ & $-0.76 * *$ & $0.39^{\circ}$ & -0.01 & $0.47^{\circ}$ & $-0.60 * *$ \\
\hline$D_{R S}$ & $0.37^{\circ}$ & 0.22 & $0.79 * *$ & $-0.79 * *$ & 0.18 & 0.32 & $0.50 *$ & $-0.60 *$ \\
\hline Soil $_{\text {Cov. Rt }}$ & $-0.46^{\circ}$ & 0.00 & $-0.92 * *$ & $0.91 * *$ & $-0.45^{\circ}$ & 0.00 & $-0.70 * *$ & $0.77 * *$ \\
\hline
\end{tabular}

Table 5. Linear correlation coefficients $(r)$ between two seasons (rainy and dry) for chemical, physical and field indicators in a Ultisol clayey.

\begin{tabular}{|c|c|c|}
\hline Indicators & $\begin{array}{c}\text { Depth } \\
(\mathrm{cm})\end{array}$ & $R$ \\
\hline \multirow{4}{*}{$\mathrm{BS}^{/ \mathrm{A}}$} & $0-5$ & $0.91 * *$ \\
\hline & $5-10$ & $0.85 * *$ \\
\hline & $10-20$ & $0.75 * *$ \\
\hline & $20-40$ & $0.89 * *$ \\
\hline \multirow{4}{*}{$\mathrm{AS}^{\mathrm{B}}$} & $0-5$ & $0.90 * *$ \\
\hline & $5-10$ & $0.30^{\circ}$ \\
\hline & $10-20$ & $0.84 * *$ \\
\hline & $20-40$ & $0.94 * *$ \\
\hline \multirow{4}{*}{$\mathrm{POM}^{/ \mathrm{C}}$} & $0-5$ & $0.90 * *$ \\
\hline & $5-10$ & $0.93 * *$ \\
\hline & $10-20$ & $0.89 * *$ \\
\hline & $20-40$ & $0.77 * *$ \\
\hline \multirow{4}{*}{$\mathrm{Ma}^{/ \mathrm{D}}$} & $0-5$ & $0.32^{\circ}$ \\
\hline & $5-10$ & $0.32^{\circ}$ \\
\hline & $10-20$ & $0.67 * *$ \\
\hline & $20-40$ & $0.32^{\circ}$ \\
\hline "A"/E & & 0.21 \\
\hline$D_{R S}^{/ \mathrm{F}}$ & & $0.62 * *$ \\
\hline Soil $_{\text {Cov. Rt }}{ }^{/ G}$ & & $0.86^{* *}$ \\
\hline
\end{tabular}


Table 6. Summary description of sites and treatments at each site.

\begin{tabular}{|c|c|c|}
\hline${ }^{\mathrm{A} /}$ Sites & Brief history & $\begin{array}{l}\text { Grazing } \\
\text { System } \\
\end{array}$ \\
\hline Forest & Secondary vegetation established for over 60 years & Ungrazed \\
\hline Capoeira & Process of natural regeneration for 7 years, undergrowth & Ungrazed \\
\hline DegradedPasture 1 & & Continuous \\
\hline DegradedPasture 2 & B. brizantha planted in 2006 , without the use of liming, or & Continuous \\
\hline DegradedPasture 3 & soil fertilization, previous management with fire & Continuous \\
\hline DegradedPasture 4 & & Continuous \\
\hline
\end{tabular}

Table 7. Level of soil quality based in visual classification on different sites.

\begin{tabular}{lcc}
\hline Sites & Visual classification & Level of soil quality \\
\hline Degraded Pasture 1 & Very strong degradation & 1 \\
Degraded Pasture 2 & Strong degradation & 2 \\
Degraded Pasture 3 & Moderate degradation & 3 \\
Degraded Pasture 4 & Slight degradation & 4 \\
Capoeira & Natural regeneration & 5 \\
Forest & Without degradation & 6 \\
\hline
\end{tabular}

Table 8. Orthogonal contrasts to compare the study sites.

\begin{tabular}{|c|c|c|c|c|c|c|}
\hline \multirow{2}{*}{$\begin{array}{l}{ }^{\mathrm{A} /} \text { Orthogonal } \\
\text { contrasts }\end{array}$} & \multicolumn{6}{|c|}{ Study sites } \\
\hline & Forest & Capoeira & ${ }^{\mathrm{B} /} \mathrm{D}$. Pasture 4 & D. Pasture 3 & D. Pasture 2 & D. Pasture 1 \\
\hline $\mathrm{C}_{1}$ & 6 & -1 & -1 & -1 & -1 & -1 \\
\hline $\mathrm{C}_{2}$ & 0 & 4 & -1 & -1 & -1 & -1 \\
\hline $\mathrm{C}_{3}$ & 0 & 0 & 3 & -1 & -1 & -1 \\
\hline $\mathrm{C}_{4}$ & 0 & 0 & 0 & 2 & -1 & -1 \\
\hline $\mathrm{C}_{5}$ & 0 & 0 & 0 & 0 & 1 & -1 \\
\hline
\end{tabular}

bases $\left(\mathrm{Ca}^{2+}, \mathrm{Mg}^{2+}\right.$ and $\left.\mathrm{K}^{+}\right)$(Shaefer et al., 2002). It should be noted that the decrease of exchangeable bases in the exchange complex reduces the BS and therefore the AS is greater. Aluminum in high levels is toxic to plants and may in turn lead to reduced growth and less depth of roots, especially as seen in Pasture areas 1 and 2. Another aspect related to smaller $D_{R S}$ can be the smaller Ma found in grazed areas (Table 5). In agreement with our results, Silva et al. (2000), found in an oat-corn rotation in a Red Ultisols, a negative correlation between density of roots and exchangeable aluminum, as well as between soil density and roots density. Muller et al. (2001) in a study in the Amazon region which the soil also is a Ultisols, found that highly degraded colonião-grass (Panicum maximum) pasture had reducted root growth, being attributed to animal grazing which led to increased soil bulk density and reduced macroporosity. In the present study the greater "A horizon" thickness favored increased Ma which in turn stimulated $D_{R S}$. These factors can be observed, especially in the areas of Forest, Capoeira and Pasture 4, which may be related to a greater presence of organic matter in the "A horizon" and increased Ma. The use of visual methods for evaluating soil quality has been shown to be effective in reducing subjectivity, especially in assessment of soil structure, compaction, root growth, among other features (McKenzie, 2013; Muphy et al., 2013; Peigné et al., 2013). In the present work, it was possible to establish field-based soil quality indicators sensitive to levels of degraded pastures, as well as to establish a practical method for the determining the levels of degradation in field with good accuracy. Furthermore, it is possible to extrapolate levels of soil quality from local field determinations to soils on a regional scale.

\section{Materials and Methods}

\section{Site description}

The study was conducted at Fazenda Guzerá Duas Meninas, situated in the municipality of Governador Valadares in the Vale do Rio Doce, Minas Gerais, geographic coordinates $18^{0}$ $47^{\prime} 28^{\prime}$ ' $\mathrm{S}$ and $41^{\circ} 59^{\prime} 17^{\prime \prime}$ (Fig.3). The 499 ha farm has a beef cattle and milking herd of 180 animals, which graze pasture planted is Brachiaria brizantha cv. Marandu. The climate of the region is the Aw type (tropical, with a dry season in winter, when the average temperature in the coldest month is higher than $18.0{ }^{\circ} \mathrm{C}$, and the driest month rainfall is less than $60 \mathrm{~mm}$ ), according to the Köppen classification. The average annual rainfall is $1133 \mathrm{~mm}$, with the highest rainfall between November and January. According to the meteorological station of Vale do Rio Doce University, the annual average temperature is $25.6{ }^{\circ} \mathrm{C}$, with maximum and minimum averages ranging from $28.7{ }^{0} \mathrm{C}$ and $18.3{ }^{\circ} \mathrm{C}$ respectively. The study area consisted of seven collection areas with dimensions of $10 \times 50 \mathrm{~m}$ (largest dimension in the opposite direction to the land slope), with a slope of $0.40 \pm$ $0.04 \mathrm{~m} \mathrm{~m}^{-1}$, allocated on the middle third of the landscape in a convex landform. The areas were at first chosen visually based on the soil exposure and the degree of infestation of spontaneous plants as follows: four degraded pastures progressively classified from largest to smallest degree of degradation (Degraded pasture 1, Degraded pasture 2, Degraded pasture 3 and Degraded pasture 4), in addition to a Capoeira and a secondary Forest used as reference (Table 6). 


\section{Soil sampling}

The soil samples for laboratory analyses were collected in two periods, rainy (November) and dry (July), at four depths $(0-5,5-10,10-20$ and 20-40 cm). Disturbed and undisturbed (volumetric ring) soil samples were collected. The disturbed soil samples were grounded and sieved through a $2-\mathrm{mm}$ sieve to remove root material and the stone fraction. The soil sieved was air dried for determining chemical and physical parameters.

\section{Laboratory indicators of soil quality}

The physical attributes of the soil were determined: soil density, determined by the volumetric ring method (Bd) (Blake and Hartge, 1986); total porosity (Tp), obtained by the relationship between the soil density and the particles density (1-Bd/Pd); microporosity (Mi), tension table $(60 \mathrm{~cm}$ water column); and macroporosity (Ma), determined by the difference between total porosity and microporosity $(\mathrm{Ma}=$ Tp-Mi).

The following chemical attributes were determined: exchangeable acidity $\left(\mathrm{Al}^{3+}\right)$, extracted with $1 \mathrm{~mol} \mathrm{~L}^{-1} \mathrm{KCl}$ and titrated with $0.025 \mathrm{~mol} \mathrm{~L}^{-1} \mathrm{NaOH}$; potential acidity $(\mathrm{H}+\mathrm{Al})$, extracted with $1 \mathrm{~mol} \mathrm{~L}^{-1}$ calcium acetate at $\mathrm{pH} 7.0$ and titrated with $0.060 \mathrm{~mol} \mathrm{~L}^{-1} \mathrm{NaOH}$; calcium and magnesium $\left(\mathrm{Ca}^{2+}\right.$ and $\left.\mathrm{Mg}^{2+}\right)$, extracted with $1 \mathrm{~mol} \mathrm{~L}^{-1} \mathrm{KCl}$ and determined by atomic absorption spectrometry (Thermo Scientific ICE-3000); and potassium and sodium $\left(\mathrm{K}^{+}\right.$and $\mathrm{Na}^{+}$), extracted with Mehlich-1 and determined by flame photometry (Digimed DM-62). The cationic exchange capacity (CEC); percentage of base saturation (BS); and percentage of saturation by aluminum (AS) (EMBRAPA, 1997) were calculated.

The total organic carbon (OC) was determined by dry combustion in a CHNS/O elemental analyzer (Perkin-Elmer CHNS/O 2400); particulate organic matter (POM) was determined using a $\mathrm{Na}_{2} \mathrm{OH}_{6} \mathrm{P}_{2} \mathrm{O}_{5}\left(5 \mathrm{~g} \mathrm{~L}^{-1}\right)$ solution as dispersant in the proportion 1:3 (soil: dispersant solution), with the light material suspending after a 16-hour rest and passed in a $0.53 \mathrm{~mm}$ sieve. After drying the material in an oven $\left(40^{\circ} \mathrm{C}\right)$, the particulate organic carbon(POC) content was quantified in the CHNS/O elemental Analyzer, and by the difference between total organic carbon (OC) and particulate organic carbon (POC) organic carbon associated with the mineral fraction of soil was calculated (MAOC) (Cambardella and Elliot, 1992).

\section{Field indicators of soil quality}

The determination of the field indicators were in two periods, rainy (November) and dry (July). For the determination of soil coverage rate (Soil Cov. Rt $_{\text {. }}$ in the Pastures areas 1, 2, 3 and 4 , the "measuring tape" method was used (Rocha Junior et al., 2014b), where a 50-m graduated tape was stretched horizontally at the top end of the portion. Each meter determining a reading which indicated the vegetation type found at intervals of $1 \mathrm{~m}$ was recorded. After the determining 50 readings on the horizontal, the readings were repeated down the slope to form a grid with a total of 500 readings per portion. Since the main characteristics of vegetation type were similar among the study areas, the readings were divided into: exposed soil, pasture, invasive narrow leaf and invasive broad leaf. This criterion was adopted since the reference areas of Forest and Capoeira was completely covered.
For the determining the "A horizon" thickness, five trenches per portion of land were digged a depth of $40 \mathrm{~cm}$, totaling five repetitions. The "A horizon" thickness was determined by measuring the "A horizon" until the transition with horizon "AB". In the same trench, the effective $D_{R S}$ was determined from the soil surface to the point of greatest concentration of the root system (Donagemma et al., 2010).

\section{Statistical analyses}

For the statistical analysis of each pasture area, a soil quality level was assigned according to the level of visual classification adopting the smaller weights on the scores for the most visually degraded areas (Table 7). The same procedure was adopted for the Forest and Capoeira areas; as neither showed visual soil degradation, the weights were higher than the grazing areas. Therefore, the Forest area received a higher score than the Capoeira, since it did not suffer with anthropic processes for at least 60 years according to history (Table 6).

The field indicator results in the various levels of soil quality were expressed as mean values, with subsequent linear correlations being performed between levels and field indicators ( $D_{R S}$ and the "A horizon" thickness). The same procedure was adopted for the Soil ${ }_{\text {Cov. Rt }}$ results which were first expressed as percentage (\%), and later correlations were adjusted with the $D_{R S}$ and the "A horizon" thickness ( ${ }^{0} \mathrm{P} \leq$ $0.20 ; * P \leq 0.05$ and $* * P \leq 0.01)$.

To evaluate whether the differences were significant, the depth of root system indicators and "A horizon" thickness were submitted to analysis of variance, where the degrees of freedom for the study areas were broken down into five orthogonal contrasts among each other, with each period of time being studied separately (Table 8 ). The contrasts significance was tested by the $\mathrm{F}$ test $\left(* P \leq 0.05\right.$ and ${ }^{* *} P \leq$ $0.01)$.

Similarly, for the validation of field indicators based on the more sensitive physical, chemical and soil organic matter attributes of degraded pastures, the significance of contrasts $(* P \leq 0.05$ and $* * P \leq 0.01$ ) (Table 3 ), were separated according to the four depths $(0-5,5-10,10-20$ and 20-40 cm). Subsequently, linear correlation coefficients were established $\left({ }^{0} P \leq 0.20, * P \leq 0.05\right.$ and $\left.* * P \leq 0.01\right)$ among the laboratory indicators and field measurements (Soil Cov. RT $_{\text {RT }}$ "A horizon" thickness and $D_{R S}$ ), in order to evaluate which ones related positively or negatively, and an attempt was made to interpret them based on theoretical aspects. Only the correlations that presented significant correlation coefficients were selected. To evaluate the variation of indicators for the sampling times, a linear correlation was made $\left({ }^{0} P \leq 0.20, * P \leq 0.05\right.$ and $* * P$ $\leq 0.01$ ) with the sampling times for all indicators.

\section{Conclusion}

Among several depths evaluated, the surface $0-5 \mathrm{~cm}$ proved to be more sensitive in assessing soil quality indicators under Pastures. Levels assigned to the study areas represented well the situation of degradation observed in the field. However, the use of the "measuring tape" method is the best option, because in addition to being less subjective, it can be easily disseminated. Field indicators of soil quality: "A horizon" thickness, depth of root system $\left(D_{R S}\right)$ and soil coverage rate are sensitive to levels of degraded pastures observed visually. Four groups are defined by means of field determinations: reference (Forest) in recovery (Capoeira), low degradation (Pasture 3 and 4) and high degradation (Pastures 1 and 2). It is suggested that the use of soil coverage rate, $D_{R S}$ and "A 
horizon" thickness are the best indicators of soil quality in degraded pastures for the studied soil and region. In relation to the time of sampling, with the exception of the "A horizon" thickness, basically no differences were found for field and laboratory indicators used, suggesting that the indicators can be used independently of the season.

\section{Acknowledgments}

The authors thank CAPES for the financial educational support, $\mathrm{CNPq}$ for the research financial support, CCA-UFES Laboratório de Solos, and EMBRAPA-Solos for the partnership in carrying out this work.

\section{References}

Albuquerque AW, Lombardi-Neto F, Srinivasan VS (2001) Efeito do desmatamento da caatinga sobre as perdas de solo e água de um Luvissolo em Sumé (PB). R Bras de Ci Solo. 25:121-128

Andrews SS, Carroll CR (2001) Designing soil quality assessment tool for sustainable agroecosystem management. Ecol Applications. 11:1573-1585.

Baruqui FM, Resende M, Figueredo MS (1985) Causas da degradação e possibilidades de recuperação das pastagens em Minas (Zona da Mata e Rio Doce). Inf Agropecuário EPAMIG. 126:27-37.

Bertossi APA, Rocha Junior PR, Ribeiro PH, Menezes JPC, Avelino RC, Andrade FV (2016) Soil cover and chemical and physical attributes in Oxisol in the Atlantic Forest Biome. Revista Árvore. 40: 219-228.

Blake GR, Hartge KH (1986) Particle density. In: Klute A (Eds). Methods of soil analysis: Physical and mineralogical methods, second ed. Madison, American Society of Agronomy, 377-382p.

Brown JH, Burnside WR, Davidson AN, Delong JR, Dunn WC, Hamilton MJ, Mercado-Silva M, Nekola JC, Okie JG, Woodruff WH, Zuo W (2011) Energetic Limits to Economic Growth. BioScience. 61(1):19-26.

Cambardella CA, Elliott ET(1992) Particulate soil organic matter changes across a grassland cultivation sequence. Soil Sci Soc Am J. 56:777-783.

Donagemma GK, Chaer GM, Balieiro FB, Andrade AG, Fernandes MF, Coutinho HL, Correia H, Barrios E(2011) Indicadores de qualidade do solo. In: Ferreira JML, Alvarenga A, Santana DP, Vilela MR (Eds.). Indicadores de sustentabilidade em sistemas de produção agrícola, 143$202 \mathrm{p}$.

Dean W (1995) With Broadax and Firebrand: The Destruction of the Brazilian Atlantic Forest. University of California Press, Berkeley, 504 p.

EMBRAPA (Empresa Brasileira de Pesquisa Agropecuária) (1997) Manual de métodos de análise do solo. Rio de Janeiro: Centro Nacional de Pesquisa de Solos, 212 p.

Favero C, Lovo IC, Mendonça ES (2008) Recuperação de área degradada com sistema agroflorestal no Vale do Rio Doce, Minas Gerais. Rev Árvore. 32:861-868.

Fonseca GAB (1985) The vanishing Brazilian Atlantic Forest. Biol Cons. 34:17-34.

Hulugalle I, Entwistle PC, Mensah RK (1999) Can lucern (Medicago sativa L.) strips improve soil quality in irrigated cotton (Gossypium hirsutum L.) fields? Appl Soil Ecol. 12: 81-92.

Islam KR, Weil RR (2000) Land use effects on soil quality in a tropical Forest ecosystem of Bangladesh. Agri Ecosyst Environ. 79: 9-16.
Landi A, Mermut AR, Anderson DW (2004) Carbon distribution in a hummocky landscape from Saskatchewan, Canada. Soil Sci Soc Am J. 68:175-184.

Lima AMN, Silva IR, Neves JCL, Novais RF, Barros NF, Mendonça ES, Demolinari MSM, Leite FP (2008) Frações da matéria orgânica do solo após três décadas de cultivo de eucalipto no Vale do Rio Doce-MG. R Bras de Ci Solo. 32:1053-1063

Lisbôa FM, Donagemma, GK, Burak DL, Passos RR, Mendonça ES (2016) Indicadores de qualidade de Latossolo relacionados à degradação de pastagens. Pesq agropec bras.. 51:1184-1193.

Manning G, Fuller LG, Eilers RG, Florinsky I (2001) Topographic influence on the variability of soil properties within an undulating Manitoba landscape. Can J Soil Sci. 81:439-447.

Martin WKE, Timmer VR (2006) Capturing spatial variability of soil and litter properties in a forest stand by landform segmentation procedures. Geoderma. 132:169181.

Martínez LJ, Zinck JA (2004) Temporal variation of soil compaction and deterioration of soil quality in pasture areas of Colombian Amazonia. Soil Till Res.75:3-18.

Martins SG, Silva MLN, Curi N, Ferreira MM, Fonseca S, Marques JJGSM (2003) Perdas de solo e água por erosão hídrica em sistemas florestais na região de Aracruz-ES. R Bras de Ci Solo. 27:395-403.

McKenzie DC (2013)Visual soil examination techniques as part of a soil appraisal framework for farm evaluation in Australia. Soil Till Res. 127:26-36.

Myers N, Mittermeier RA, Mittermeier CG, Fonseca GAB da Kent J (2000). Biodiversity hotspots for conservation priorities. Nature. 403: 853-858.

Muller MML, Guimarães MF, Desjardins T, Martins PFS (2001) Degradação de pastagens na Região Amazônica: propriedades físicas do solo e crescimento de raízes. Pesq Agropec Bras. 36:1409-1418.

Munkholm LJ, Heck RJ, DeenB (2013) Long-term rotation and tillage effects on soil structure and crop yield. Soil Till Res.127:85-91

Murphy BW, Crawford MH, Duncan DA, McKenzie DC, Koen TB (2013) The use of visual soil assessment schemes to evaluate surface structure in a soil monitoring program. Soil Till Res. 127:3-12.

Nascimento MC, Riva RDD, Chagas CS, Oliveira H, Dias LE, Fernandes-Filho EI, Soares VP (2006) Uso de imagens do sensor ASTER na identificação de níveis de degradação em pastagens. Rev Bras Eng Agric Ambient. 10:196-202.

Passos RR, Costa LM, Burak DL, Santos DA (2015) Quality indices in degraded pasture in hilly relief. Semina. 36:2465-2482.

Peigné J, Jean-Fraçois V, Cannavacciuollo M, Lefevre V, Gautronneau Y, Boizard H (2013) Assessment of soil structure in the transition layer between topsoil and subsoil using the profil cultural method. Soil Till Res. 127:13-25.

Ribeiro MC, Metzger JP, Martensen AC, Ponzoni F, Hirota MM (2009) Brazilian Atlantic forest: how much is left and how is the remaining forest distributed? Implications for conservation. Biol Cons. 142:1141-1153.

Rodrigues RR, Lima RAF, Gandolfi S, Nave AG (2009) On the restoration of high diversity forests: 30 years of experience in the Brazilian Atlantic Forest. Biol Cons. 142:1242-1251.

Rocha Junior PR, Soares ML, Ribeiro IG, Costa ASV, DonnagemmaGK, MendonçaES (2014a) Soil carbon stock in silvopastoral system, pasture and sugarcaneculture. Idesia. 32:35-42. 
Rocha Junior PR, DonnagemmaGK, Andrade FV, Passos RR, Balieiro FC, Mendonça ES, Ruiz HA (2014b) Can Soil organic carbon pools indicate the degradation levels of pastures in the atlantic forest biome? J Agric Sci. 6:84-95.

Ruiz-Jaen MC, Aide TM (2005) Restoration success: how is it being measured? Restor Ecol. 13:569-577.

Santana MB, Silva LS, Souza LD, Fontes LEF (2006) Atributos físicos do solo e distribuição do sistema radicular de citros como indicadores de horizontes coesos em dois solos de tabuleiros costeiros do estado da Bahia. R Bras de Ci Solo. 30:1-12.

Schaefer CEGR, Silva DD, Paiva KWN, Pruski FF, Albuquerque-Filho MR, Albuquqerque MA (2002) Perda de solos, nutrientes, matéria orgânica e efeitos microestruturais em Argissolo Vermelho-Amarelo sob chuva simulada. Pesq agropec bras. 37(5):669-678.

Silva VR, Reinert DJ, Reichert JM (2000) Densidade do solo, atributos químicos e sistema radicular do milho afetados pelo pastejo e manejo do solo. R Bras de Ci Solo. 24:191199.
Silva DD, Pruski FF, Schaerfer CEGR, Amorin RSS, Paiva KWN (2005) Efeito de cobertura nas perdas de solo em um Argissolo Vermelho-Amarelo utilizando simulador de chuva. R Bras de Eng Agr e Ambiental. 25:409-419.

Silva MA, Silva MLN, Curi N, Norton LD, Avanzi JC, Oliveira AH, Lima GC, Leite FP (2010) Water erosion modeling in a watershed under forest cultivation through the USLE model. $19^{\text {th }}$ World Congress of Soil Science, Soil Solutions for a Changing World 1 - 6 August, Brisbane, Australia, 173-176.

Tobiasova E (2011) The effect of organic matter on the structure of soils of different land uses. Soil Till Res. 114:183-192.

Vanwalleghem T, Poesen J, McBratney A,Deckers J (2010) Spatial variability of soil horizon depth in natural loessderived soils. Geoderma.157:37-45. 